\title{
Some Secondary Sources of Acquisition of Community Property
}

$I^{N}$ $\Lambda$ PREvIOUS papers acquisition of community property by adverse possession and by improvements on land has been discussed, as have also the primary sources of acquisition, through the earnings of the spouses, the rents, issues and profits of separate property ( in some states), and borrowed money and credit purchases. ${ }^{2}$ Two other sources remain to be examined; namely, the proceeds of insurance policies, and recoveries for personal injuries.

\section{The Proceeds of Insurance Policies.}

The writer regrets that a discussion of the problems involved in determining whether or not the proceeds of life insurance policies are to be regarded as assets of the community of husband and wife, was quite outside the scope of the admirable article recently published by Professor Vance. ${ }^{2}$ What he there states as being the prevailing rule, viz: that the interest of the sole beneficiary of a life insurance policy is vested where no right to change the beneficiary is reserved by the insured, obtains likewise in the community property 'states.

A different result might conceivably have been reached where community assets are used to pay premiums, even though that rule applied in other cases. The usual rule relating to community property is that the right or thing purchased follows, as to the nature of the ownership of it, the funds used to purchase it. Where, however, improvements are attached to land, they follow, as to ownership, the land rather than the nature of the funds invested in them. ${ }^{3}$ So it is held that the nature of the rights arising from life insurance policies, whether separate or community, is determined by the beneficiary, rather than by the nature of the funds used to pay premiums.

It has been held in Texas that where the wife is the beneficiary she is not entitled to take under the policy if she is subsequently

1 Some Sources of Acquisition of Community Property, 31 Yale Law Journal, 734; Primary Sources of Community Property, 10 California Law Review, 271. It is regretted that an error appears in the latter paper. The writer asks that the words "and is now save as to the wife's property," in the first line of page 277 ; and the words in brackets at the top of page 279 and the word "partly" in the fourteenth line of the same page be disregarded.

231 Yale Law Journal. 343.

${ }^{3}$ Knight v. Kaufman (1900) 105 La. 35, 29 So. 711; Haring v. Shelton (1908) 114 S. W. 389 (Tex. Civ. App.). 
divorced before the husband's death." She cannot claim an interest in the community funds used to pay premiums because the property interests were settled on divorce, nor can she claim an interest in the surrender value because, as said in Whitselle $v$. Northwestern Mutual Life Insurance Co., ${ }^{5}$ no surrender value existed as a matter of right. If as a fact there was a surrender value under the policy it is difficult to see how it was not as much vested in the wife as her interest in the proceeds on the husband's death would be. A different conclusion is reached in California in regard to the effect of divorce. ${ }^{b}$ Professor Vance indicates that where a power is reserved to change the beneficiary, there are two views taken as to the nature of the interest of the beneficiary: (a) that it is like an expectancy under the draft will of a living testator and (b) that the beneficiary takes a vested interest subject to a power of appointment in the insured. Under either view the Texas case would seem to be wrong, because just as a legatee's interest vests at death of the testator, so, where the person who is to take on death of insured is named and the event on which she is to take occurs, the happening of some other event such as divorce cannot divest such interest.

Where policies are issued on the life of one spouse in favor of the other, the proceeds on the death of the insured are invariably held to be separate. ${ }^{7}$ Where the husband's life is insured in favor of the wife, it is held that he has a right to make a gift to her of such portion of the community funds as were used and a gift is presumed. The husband, being the manager of the community estate, can divert community funds to pay premiums on a policy upon the wife's life although he is the beneficiary named in the policy, and the proceeds on her death will be his separate property. ${ }^{8}$ He has absolute power to invest community funds as

4 Hatch v. Hatch (1904) 80 S. W. 411 (Tex. Civ. App.) ; Speer, Law of Marital Rights in Texas, \$363.

5 (1920) 221 S. W. 575 (Tex. Com. App.)

${ }^{6}$ McGrew v. Mut. B. Life Ins. Co. (1901) 132 Cal. 85, 64 Pac. 103, 84 Am. St. Rep. 20; Courtois v. Grand Lodge of Workmen (1902) 135 Cal. 552, 67 Pac. 970, 87 Am. St. Rep. 137. See also note in 39 L. R. A. (N. S.) 370, and Wallace v. Mut. Ben. Life Ins. Co. (1906) 97 Minn. $27,106 \mathrm{~N}$. WV. 84.

7 Evans v. Opperman (1890) 76 Tex. 299, 13 S. W. 312; Putnam v. N. Y. Life Ins. Co. (I890) 42 La. Ann. 739,7 So. 602 ; Martin v. Moran (1895) 11 Tex. Civ. App. 509, 32 S. W. 904; Sullivan v. Sullivan (1893) 99 Cal. 187, 33 Pac. 862.

8 Martin v. Moran, supra, n. 7; Rowlett v. Mitchell (1909) 52 Tex. Civ. App. 627, $114 \mathrm{~S}$. W. 845 . It has also been held that it is possible for the husband to divert community funds in paying premiums on a policy on his own life, a stranger being the beneficiary, if no fraud on the wife is shown. Gristy 
he chooses, providing there is no fraud on the wife. Would a court take the next step and say that the sum received on surrender of such a policy would be or continue separate when purchased with community funds? Surely not, if there was a right reserved in the wife to change the beneficiary; but if there were no such right reserved one can only conjecture the result. Since it would not be acquired by gift, devise or descent, it should belong to the community.

The proceeds of a policy procured by a man or woman before marriage are separate, the nature thereof being determined by the date of the policy, with reference to marriage, but it has been held that payments of premiums out of community funds may be recovered by the community. ${ }^{10}$

If the proceeds of a policy on the husband's life are payable to his estate, ${ }^{11}$ or as directed to be paid in his will, ${ }^{12}$ and his will makes them payable to his executors, the premiums being paid from community funds, they belong to the community on his death, since he cannot make a gift to himself. In Succession of Le Blanc, ${ }^{18}$ the husband had taken out two policies in favor of his wife, "to be paid to her if she were living at his death, if not to his personal representatives." The wife having died first, it was held that the proceeds on his death were community, but the payments made out of his separate property after the wife's death were recoverable against the community.

Where the beneficiary dies before the insured and no right to change the beneficiary is reserved in the policy, the proceeds go to the heirs of the beneficiary because the interest was vested. ${ }^{14}$ If there is a right to change the beneficiary, then, according to Professor Vance, there is no vested interest in the beneficiary, ${ }^{15}$ and on

v. Hudgins (1922) 203 Pac. 569 (Ariz.). Cf. Sheehan v. Journeymen etc. Ass'n. (1904) 142 Cal. 489, 76 Pac. 238.

9 Hatch v. Hatch, supra, n. 4; In re Moseman's Estate (1886) 38 La. Ann.

219. See note in $56 \mathrm{I}$. R. A. 585.

10 In re Moseman's Estate, supra, n. 9.

11 Succession of Buddig (1902) 108 La. 406, 32 So. 361 ; Aetna Life Ins. Co. v. Osborne (1920) 224 S. W. 815 (Tex. Civ. App.).

12 Martin v. Moran (1895) it Tex. Civ. App. 509, 32 S. W. 904. The proceeds of a policy on the life of a single man, made payable to his heirs, constitute no part of his estate on his death. Schonfield v. Turner (1889) 75 Tex. 324, 12 S. W. 626, 7 L. R. A. 189; Mullins v. Thompson (1879) 51 Tex. 7. See Speer, \&325.

13 (1917) 142 La. 27, 76 So. 223, L. R. A. 1917 F. 1137.

14 In re Dobbel's Estate. (1894) 104 Cal. 432,38 Pac. 87, 43 Am. St. Rep. 123. Cf. note in 11 Am. St. Rep. 721. See Vance on Insurance, \$\$ 132-134, note 32.

15 Vance on Insurance, $\$ 136$. 
his prior death no interest would come to his heirs. In Wooden v. Wooden, ${ }^{16}$ the insured had a right under the policy to change the beneficiary. The proceeds were payable, a portion to the wife and the remainder to his two sons. On the death of one of the sons before the insured, it was held that the deceased's share became community property of his father and mother and so passed onehalf to the widow and the remainder to the surviving son. The case therefore supports the theory advanced by Professor Vance, as to the nature of the interest of a sole beneficiary when the right to change is reserved.

A father may procure insurance on his own life in favor of his children by a former marriage, or other dependent relatives, and although community funds have been used in payment of the premiums, the proceeds, on his death, are the separate property of the beneficiaries, provided that no unreasonable sum, in proportion to the community assets remaining, was used in the payment of the preniums. ${ }^{17}$ Thus where a policy for $\$ 1,000$ in favor of children of a prior marriage was taken out after the second marriage, the sum paid for premiums amounting to $\$ 73.20$ and the remaining community assets amounting to $\$ 450$, there was no fraud on the wife's right. $^{18}$ In Jones v. Jones, ${ }^{19}$ the husband left a policy of $\$ 7,500$ for his son and $\$ 4,000$ in favor of his wife, and $\$ 3,000$ for his estate. $\mathrm{He}$ had changed the beneficiary of another policy in the sum of $\$ 2,000$, making his father the beneficiary thereof instead of his wife, and the estate amounted to $\$ 15,000$ in addition. It was held that he had a right to provide for his father in a much larger sum than he had done, although the premiums were paid with community funds, this being no fraud on the wife.

Suppose a policy on the husband's life in favor of the wife, having a surrender value, is surrendered during the lifetime of the latter: to whom do the proceeds go? Logically the mere surrender of the policy would not affect a vested interest The beneficiary has the right to keep the policy in force by paying the premiums.

16 (1909) 116 S. W. 627 (Tex. Civ. App.). A mere assignment is not the exercise of a power to change the beneficiary. Douglass v. Equitable Life Assur. Soc. (1922) 90 So. 834 (La.).

17 A father's obligation to care for his children by a former marriage in the future justifies taking out a policy in their favor, just as his obligation to care for them in the present justifies an expenditure out of the community property of a second community. Succession of Applegate (1887) $39 \mathrm{La}$. Ann. 400,2 So. 42.

18 Rowlett v. Mitchell (1908) 52 Tex. Civ. App. 589, 114 S. W. 845.

19 (1912) 146 S. W. 265 (Tex. Civ. App.). 
In Hall v. Levy, ${ }^{20}$ an endowment policy in favor of the wife was liquidated by the payment to the husband of $\$ 5,000$. The trial court held that the funds thus realized were the property of the community. On appeal it was said: "The decision of the case does not alone depend upon the character and effect of the insurance policy; for in addition to having his life insured in favor of Bertha Baum ... D. Baum delivered the proceeds of the liquidated policy to her" (as a gift). The implication seems to be that the fund was already hers before the delivery.

If, however, there is a right to change the beneficiary, then the proceeds, upon surrender and liquidation of the rights under the policy, would seem to be community if the premiums had been paid with community funds. If the designation of the beneficiary is a mere instruction to "the insurer of the insured's then desire in regard to the payment of the proceeds in the event of his death," a surrender may be regarded as a declaration of change of desire like an ademption, and the proceeds should follow the nature of the funds in procuring the policy.

Proceeds of fire insurance policies follow the nature of the property insured as a matter of course. ${ }^{23}$ It has been held that the fact that a policy was taken out by the wife on the husband's separate premises does not change the proceeds so as to make them community. ${ }^{22}$ The wife had, however, an insurable interest because she obtained a profit from the premises, which were used as the family residence. If she insures community furniture and a loss occurs, the husband is the proper plaintiff to bring the action there-

20 (1903) 31 Tex. Civ. App. 360, 72 S. W. 263. It has been held in Louisiana that the proceeds of an endowment policy taken on the husband's life in favor of the wife, maturing before the husband's death, are separate property of the wife. Succession of Des Forges (1914) 135 La. 49, 64 So. 978, 52 L. R. A. (N. S.) 689 . It is arguable that while the proceeds are payable to the wife, she takes for the community because such proceeds do not come within the statutory definition of separate property. That the husband cannot surrender or assign so as to divest the wife's separate interest where such power is not reserved, see Putnam v. N. Y. Life Ins. Co. (1890) 42 La. Ann. 739, 7 So. 602; Lambert v. Penn. Mut. Life Ins. Co. (1898) 50 La. Ann. 1027, 24 So. 16.

21 When a building on a homestead, being insured, is destroyed by fire, the insurance company is not subject to garnishment by one who holds an unsatisfied mechanics lien on the building. Cameron v. Fay (1881) 55 Tex. 58.

22 Rolater v. Rolater (1917) 198 S. W. 391 (Tex. Civ. App.). But the husband has no insurable interest in the wife's separate property and the policy is void. St. Paul F. \& MY. Ins. Co. v. McQuary (1917) 194 S. W. 491 (Tex. Civ. App.). 
for. ${ }^{23}$ The wife is therefore able to create rights in favor of the community.

A concubine who pays the premiums for a policy on the life of the insured is entitled to the full proceeds on his death. ${ }^{24}$ But if the payments are made by the insured as a mere gratuity,"s she can recover only one-tenth of the proceeds of the policy under the statutes of Louisiana.

\section{Damages Recovered for Personal In Juries.}

Damages recovered for personal injuries to spouses, suffered after marriage, belong to the community because, though acquired during the continuance of the marriage relation, they are not acquired by gift, bequest, devise or descent. ${ }^{28}$ There is some tendency to make such acquisitions separate when the injury is to the wife. Thus, in Louisiana ${ }^{27}$ the civil code was amended in 1902 to the effect that damages recovered for personal injuries to the wife are separate and recoverable by the wife alone. A similar change was made in Texas in 1915, ${ }^{28}$ but the husband may still bring the action alone or he may join her as plaintiff. Apparently a count for consequential damages may still be joined therewith. In California, ${ }^{29}$ the wife may sue alone for such injuries but the amount recovered still belongs to the commumity.

The causes of injuries are of course as varied as are the possible

23 Allemania Fire Ins. Co v. Angier (1919) 214 S. W. 450 (Tex. Civ. App.). Compare Germania Fire Ins. Co. v. Bally (1918) i9 Ariz. 580, 173 Pac. 1052, 1 A. L. R. 488.

24 Succession of Johnson (1905) 115 La. 20, 38 So. 880.

25 N. Y. L. Ins. Co. v. Neal (1905) 114 La. 652, 38 So. 485.

28 McFadden v. Santa Ana O. \& T. St. Ry. Co. (1891) 87 Cal. 464, 25 Pac. 681; Neale v. Depot Co. (1892) 94 Cal. 425,29 Pac. 954 . If the injury was suffered before the marriage but the recovery was after the marriage, the amount so recovered is separate. St. L. S. W. Ry. v. Wright (1903) 33 Tex. Civ. App. 80, 75 S. W. 565 (vulgar and obscene language used in presence of plaintifi). In contrast with damages recoverable for personal injuries, the damages recoverable for injuries to property depend as to ownership on the ownership of the property injured. The damages will be community property if community property is injured, but if separate property is injured the damages would be separate, Leeds v. Reed (1896) $36 \mathrm{~S}$. W. 347 (Tex. Civ. App.), and the wife if deserted may sue therefor alone. Word v. Kennon (1903) 75 S. W. 334 (Tex. Civ. App.) ; Galveston H. \& S. A. Ry. Co. v. Silegman (1893) 23 S. W. 298 (Tex. Civ. App.) ; Vazquez v. Valdez, infra, n. 80 .

${ }_{27}$ Harkness v. Louisiana \& N. W. Ry. Co. (1903) 110 La. 822,34 So. 791.

28 Texas Civil Code, Art. 4621a; Texarkana Tel. Co. v. Burge (1917)

192 S. W. 807 (Tex. Civ. App.). See Ayo v. Robertson (1919) 207 S. IV. 979 (Tex. Civ. App.); Pullman v. Cox (1920) 220 S. W. 599 (Tex. Civ. App.); Tex. Civ. Code, Art 1839.

${ }^{29}$ Cal. Code Civ. Proc. \$370; Johnson v. Hendrick (1919) 45 Cal. App. 317, 187 Pac. 78 ?. 
acts of negligence and there is no need to attempt to enumerate them exhaustively. Thus they may arise from negligent acts of common carriers toward passengers, licenses; or others; ${ }^{30}$ from assault and battery, ${ }^{31}$ including indecent assaults; $;^{32}$ from the mistake of a druggist in delivering morphine instead of quinine ; $^{33}$ from the non-delivery of medicine by an express company ${ }^{34}$ from the kidnapping of a child ${ }^{35}$ which gives rise to physical and mental distress of the parents and to pecumary loss; from failure to transmit news, resulting in mental suffering $; 0$ from injuries to personality (as well as to substance) arising from slander, false imprisonment, or malicious prosecution, ${ }^{37}$ and the like. Included within this discussion are injuries to children resulting in loss of services, ${ }^{38}$ and death of children by wrongful act. ${ }^{30}$

\section{a. Mental and Physical Injuries}

A husband may recover damages for failure of defendant express company to deliver a package of medicine shipped for the wife's use. ${ }^{10}$ The damages are based on the suffering of the wife and there can be no recovery for his own sympathetic mental suf-

${ }^{30}$ Gallagher v. Bowie (1886) 66 Tex. 265, 17 S. W. 407 ; C. R. I. \& G. Ry. Co. v. Oliver (1913)-159 S. W. 853 (Tex. Civ. App.) ; McKune v. Santa Clara M. \& L. Co. (1895) 110 Cal. 480, 42 Pac. 980.

31 Labonte v. Davidson (1918) 31 Idaho 644, 175 Pac. 588; Elzell v. Dodson (1883) 60 Tex. 331.

32 Schneider v. Biberger (1913) 76 Wash. 504, 136 Pac. 701; St. L. \&

S. W. Ry. v. Griffith (1896)' 35 S. W. 741 (Tex Civ. App.).

ss Brunswig v. White (1888) 70 Tex. 504, 8 S. W. 85.

34 Pac. Expr. Co. v. Black (1894) 27 S. W. 830 (Tex. Civ. App.).

35 Magnunson v. O'Dea (1913) 75 Wash. 574, 135 Pac. 640.

${ }^{36}$ Loper v. W. U. Tel. Co. (1888) 70 Tex. 689,8 S. W. 600; Southwestern T. \& T. Co. v. Dale (1894) 27 S. W. 1059 (Tex. Civ. App.).

${ }^{37}$ Martin v. Derenbecker (1906) 116 La. 495, 40 So. 849; Davis v. Davis (1916) 186 S. W. 775 (Tex. Civ. App.); Gomez v. Scanlan (1909) 2 Cal. App. 579, 84 Pac. 50; Nickerson v. Nickerson (1886) 65 Tex. 281; M. K. \& T. Ry. Co. v. Groseclose (1911) 134 S. W. 736 (Tex. Civ. App.); Williams v. Casebeer (1899) 126 Cal. 77, 58 Pac. 380; Meyerson v. Alter (1882) 11 Fed. 688 (C. C. La.); Lamb v. Harbaugh, infra, n. 85.

${ }^{33}$ St. L. Ry. Co. v. Campbell (1903) 75 S. W. 564 (Tex. Civ. App.); Keena v. United R. of San Francisco (1922) $36 \mathrm{Cal}$. App. Dec. 293, 37 Cal. App. Dec. 671,207 Pac. 35. It should be noted that the Supreme Court, in denying transfer to it of the latter case (1922) 63 Cal. Dec. 581, modified the decision of the District Court of Appeals in certain respects, referred to subsequently.

${ }^{39}$ G. H. \& S. A. Ry. Co. v. Hughes (1905) 91 S. W. 643 (Tex. Civ. App.) ; S. A. St Ry. Co. v. Melcher (1894) 87 Tex. 628, 30 S. W. 899. Cf. Brunswig v. White, supra, n. 33; C. R. I. \& G. Ry. Co. v. Oliver, supra, n. 30; Crevelli v. St P. Ry. Co. (1917) 98 Wash. 42, 167 Pac. 66, L. R. A. 1918-A 206; Vinette v. N. P. Ry. Co. (1907) 47 Wash. 320, 91 Pac 975, 18 L. R. A. (N. S.) 328; Williams v. T. \& P. Ry. Co. (1883) 60 Tex. 205.

to See supra, n. 34. Compare Western Union Tel. Co. v. Waller (1921) 233 S. W. 1026 (Tex. Civ. App.). The Texas cases here cited antedate of course the statutory provision referred to in note 28 , supra. 
fering nor for physician's services. In Loper v. W. U. Tel. Co., ${ }^{41}$ the sick son of plaintiff gave a message to defendant to transmit to his mother. For failure to transmit the same by defendant it was held that a community cause of action urose for the injury caused the wife, one element of which was her mental suffering. Likewise in S. T. $\&$ T. Co. v. Dale, ${ }^{42}$ a written message was handed to defendant to be delivered to the wife's mother; as a consequence of the failure to deliver it, the grandmother was not present during the last illness and death of plaintiff's child. Plaintiff was permitted to recover in behalf of the community for the mental suffering thus caused himself and his wife, in a single action.

A ininor may recover by next friend for inconvenience and injuries suffered by himself and his wife caused by a nuisance. ${ }^{33}$ If the wife has been injured by the careless letting down from the poles of a telephone line over the highway, by some third person, so that it obstructs travel, a cause of action to the community arises. 44 A similar recovery may be had for injuries to a spouse resulting from defective sidewalks or bridges; $;^{45}$ or for the wrongful expulsion of the husband from a passenger coach causing him humiliation, and mental distress on account of anxiety felt for his sick wife who remained thereon. ${ }^{48}$

Of course the injury complained of must have been proximately caused by defendant's negligence ${ }^{4 t}$ and if the wife's own act, that of climbing down from a moving train, caused the injury, the community cannot recover. In one case an action for divorce was brought. ${ }^{48}$ The only community property possessed by the spouses consisted of a cause of action for injuries to the husband arising while the latter was a brakeman for a certain railroad company. This right of action was divided between them. It may also be observed that the fellow-servant rule does not apply to prevent a

11 Supra, n. 36.

42 Supra, n. 36.

- 13 Texas \& P. Ry. Co. v. Alexander (1896) 35 S. W. 9 (Tex. Civ. App.).

4t Texarkana Tel. Co. v. Burge (1917) 192 S. W. 807 (Tex. Civ. App.).

15 Giffen v. City of Lewiston (1898) 6 Idaho 231, 55 Pac. 545; Davis v. City of Seattle (1905) 37 Wash. 223, 79 Pac. 784; Maynard v. Jefferson Co. (1909) 54 Wash. 351, 103 Pac. 418.

48 Lindsay v. O. R. R. \& N. Co. (1907) 13 Idaho 477, 90 Pac. 984, 12 L. R. A. (N. S.) 184.

47 Fournet v. Morgan's Co. (1891) 43 La. Ann. 1202, 11 So. 541.

48 Ligon v. Ligon (1905) 39 Tex. Civ. App. 392, 87 S. W. 838 . In Houston \& T. C. Ry. Co. v. Helm (1906) 93 S. W. 697 (Tex. Civ. App.) a divorce was granted after the injury to the husband had occurred. The decree provided that all property received by either spouse from the other was to be restored. It was held that such decree divested the wife of any interest she otherwise had in the cause of action. 
recovery where the wife is injured through the negligence of the husband's fellow-employee. ${ }^{49}$ The fellow-servant doctrine, being based upon the assumption of risk of the husband, would not apply to the wife because she has assumed no such risk, being a stranger to the husband's contract. It is mere chance that the husband profits, if profit he actually does, by such casualty.

\section{b. Slander, Malicious Prosecution, False Imprisonment, and Deceit}

In Davis v. Davis, ${ }^{50}$ plaintiff's father-in-law had slandered her by spreading the report that she was enceinte at the time of her marriage by a person other than the man she married. The husband, son of defendant, having abandoned the plaintiff, it was held that she could sue alone but there is no finding that the damages to be recovered were separate. It was held that the husband could not collude with defendant to defeat the just demands of the wife (commit a waste of the community estate) and that the wife need not be in actual want in order to bring an action for the recovery of community property. In another case the wife recovered for the former community, in an action for malicious prosecution of the husband in his lifetime, he having been accused of embezzlement by defendant.51 In Williams v. Casebeer, ${ }^{82}$ both spouses had been prosecuted for theft of a deed. They brought a joint action for malicious prosecution and for the loss of the wife's services. It was held that there was a misjoinder of causes but not of parties. In another case, ${ }^{53}$ the wife brought an action as sole plaintiff alleging damages to her separate property, injuries to her person, injuries to her character and injuries to the persons of her daughters. It was held that there was a misjoinder of causes, and also a defect of parties, the wife not being able to sue alone on any of these causes of action unless she is separated from her husband by his fault. i. e., deserted by him.

The wife may recover in an action for deceit against a defendant who purposely gives a false character to the husband so that as a result of the false representations the wife refuses to see him and by her treatment drives him from home and causes herself

19 Fordyce v. Dixon (1888) 70 Tex. 694, 8 S. W. 504.

50 Supra, n. 37.

31 M. K. \& T. R. v. Groseclose (1911) 134 S. W. 736 (Tex. Civ. App.).

32 Supra, n. 37. Cf. Gomez v. Scanlan (1906) 2 Cal. App. 579, 84 Pac. 50.

${ }^{53}$ Lamb v. Harbaugh, infra, n. 85. 
to be deserted.54 The cause of action belonged to the community and the husband was not joined as a party. The wife was not deserted by the fault of the husband. It was held that the failure to raise the question of defect of parties in the pleadings waived it. It would be interesting to speculate what the result would have been if the question of defect of parties plaintiff had been properly. raised.

\section{c. Death by Wrongful Act, Contributory Negligence}

An action was brought by a widow to recover damages for mental suffering arising from the failure of defendant telegraph company to deliver a message announcing the shooting of her husband.5s The direct consequence of this failure was her inability to see him before he died. It was held that the damages recoverable were not community property because they arose at the termination of the marriage relationship. A sinular observation may be made with reference to suits for death by wrongful act under the modern replicas of Lord Campbell's Act.58 The statute will not be extended by implication so as to give a spouse a cause of action when such spouse is not expressly mentioned. ${ }^{5 t}$

Recently an interesting case, Brodie v. The Washington II: P. Co.j8 arose in Washington. The husband had been injured by defendant and had brought an action for damages therefor and a settlement was effected. Subsequently, as was alleged, he died as

st Work v. Campbell (1912) 164 Cal. 343, 128 Pac 943, 43 L. R. A. (N. S.) 581 . See John E. Hannigan, "Damages Recoverable by Husband for Injury to the Wife," 16 Columbia Law Review, 22.

${ }_{55}$ W. U. Tel. Co. v. Kelley (1894) 29 S. W. 408 (Tex. Civ. App.). See Speer, §323.

56 Redfield v. Oakland \& C. St. Ry. Co. (1895) 110 Cal. 277, 42 Pac. 822 ; Thompson v. Seattle R. S. Co. (1912) 71 Wash. 436, 128 Pac. 1070 . See notes in $126 \mathrm{Am}$. St. Rep. 119, 3 Ann. Cas. 103, and 94 Am. Dec. 591 ; Speer, \$ 324; Johnson v. Seattle Elec. Co. (1905) 39 Wash. 211, 81 Pac 705.

57 Flash v. W. R. Co. (1915) 137 La. 352, 68 So. 636, L. R. A. 1916 E 113. See Thompson v. Seattle $R$ \& C. Co., supra, n. 56, apparently contra. There inay be a recovery by the husband for damages for loss of services of the wife and for funeral expenses even though he may not recover for her death caused by wrongful act. Philby v. Northern Pac. Ry. (1907) 46 Wash. 173, 89 Pac. 468.

58 (1916) 92 Wash. 574, 159 Pac. 791. See Rowe v. Richards (1915) 35 S. D. 201, Ann. Cas. 1918-A 294; Earley v. Pac. Electric Ry. Co. (1917) 176 Cal. 79, 167 Pac. 513; compare Phila. etc. Rx. v. Schubert (1911) 224 U. S. 603. See "Death," 17 C. J. $\$ \S 50,86,97,102$. In Groom v. Bangs (1908) 153 Cal. 456, 96 Pac. 503, the husband and wife had originally brought an action against a physician for damages for injuries occasioned by the unskillful treatment of the wife. Some months later, and before the trial, she died. The husband thereupon filed an amended complaint seeking damages for her death occasioned by wrongful act. It was held that the filing of an amended complaint was in effect a discontinuance of the former 
a result of the same injuries. Thereafter the widow brought an action for damages for his death caused by wrongful act of defendant. The court decided that the former settlement was a bar to this action although the husband's claim for damages and the wife's claim were separate causes, thus by interpretation making an important alteration in the seeming effect of the statute. In Martin v. Cunningham ${ }^{3 \theta}$ it was said that a release to the employer of a cause of action for a consideration was a bar to a subsequent action against the employer's physician for malpractice. The release recited that it was given, inter alia, "in full settlement of all kinds of claims." The apparent effect of such a holding is to make such a settlement over into a contract made for the benefit of unnamed third persons, the liability of such third persons being in all probability (so far as the opinion shows) never thought of at the time.

In Ostheller v. Spokane \& I. E. R. Co., ${ }^{60}$ the spouses were both instantly killed by defendant, the deaths being occasioned, in part at least, by the negligence of the husband in driving upon the track without seeing the approaching train. In the action brought by the wife's heirs for her death by wrongful act, it was held that no recovery could be had; that, although the cause of action contemplated by the statute was a new one and not the survival of an old one, yet the right to recover depended on the right of deceased to recover if the injuries had not resulted in death; that the wife could not have sued alone because the husband is a necessary party and the claim would have been a community asset; that the husband could not have sued because of his contributory negligence.

Damages arising from the statutory cause of action for death of a child by a wrongful act belong to the community because they

action and the beginning of another; that the proper way to attack it was by motion to strike, rather than by demurrer. It is interesting to observe that not only was a new cause of action set out in the amended complaint but also that the damages to be recovered would have an entirely different character, since in the first cause of action they would belong to the community but in the second to the husband only.

59 (1916) 93 Wash. 517, 161 Pac. 355; L. R. A. 1918A 225. In an action by the widow under the Federal Employers' Liability Act she may recover though deserted, if his legal liability still continued and he had an existing earring capacity so that pecuniary assistance from him might have been enforced. Fogarty v. N. P. Ry. Co. (1913) 74 Wash. 397, 133 Pac. 609, L. R. A. $1916 \mathrm{C} 800,85$ Wash. 90,147 Pac. 652, L. R. A. 1916C 803. See also Shebley v. Peters (1921) 62 Cal. Dec. 217, 200 Pac. 364.

Bo (1919) 107 Vash. 678, 182 Pac. 630. Accord, Wilson v. Brown (1912) 154 S. W. 322. (Tex. Civ. App.). (The wife was murdered by her husband, the stepfather of her children, in whose favor an action was brought for her death by wrongful act). See Texas Civ. Code Art. 4695; compare Dunbar v. San Francisco Ry. Co. (1921) 62 Cal. Dec. 469, 201 Pac. 330. See also "Death" 17 C. J. \$92, note 54. 
were not acquired by gift, bequest, devise or descent during the continuance of the marital relation. ${ }^{61}$ In Texas the statute has been interpreted to mean that both spouses are proper parties, but although the statute also provides for apportionment by the jury between the plaintiffs, a failure to apportion does not effect the validity of the judgment. ${ }^{62}$ If the employment of a child from which death resulted was induced by the fraudulent misrepresentation of his age by the father, and the only wrong of the employer is the statutory wrong of employing a minor under a given age, no recovery can be had, the misrepresentation being called by the court contributory negligence. The father being barred, the mother likewise cannot recover. ${ }^{83}$ The contributory negligence of the mother likewise will prevent a recovery by the father for death of a child by wrongful act. ${ }^{64}$ The reason is, presumably, that her negligence is the negligence of the community entity. Of course damages recoverable at common law for loss of services of a child killed by wrongful act belong to the community and the father may also recover for expenses incurred by reason of the exposure of the child, though not for the tort to the child. ${ }^{65}$

Recovery of damages for the premature birth and death of a child occasioned by injury to the mother while enceinte has been

61 Keena v. United Railroads, supra n. 38. The Supreme Court, disapproves, however, of that part of the decision dividing the proceeds between the parents.

62 G. H. \& S. A. Ry. Co. v. Hughes (1905) 91 S. W. 643 (Tex. Civ. App.). See cases cited in Vernon's Sayles' Civil Code of Texas 1914, Arts. 1838, 46944704a, 6648, note 126; and the same Arts. in the 1918 supplement. See Speer, \$ 323. For Arizona, see DeAmado v. Friedman (1907) 11 Ariz. 56, 89 Pac. 588, and Revised Statutes of Arizona for 1913, paragraphs 3372-3375. See also Cal. Code Civ. Proc. \$§ 375-377, Revised Laws of Nevada for 1919 \$\$ 49954997. For measure of damages for the death of a child by wrongful act, see DeAmado v. Friedman, supra.

${ }^{63}$ Crevelli v. C. M. \& St. Paul Ry. Co. (1917) 98 Wash. 42, 167 Pac. 66, L. R. A. 1918A 206. One should compare the result reached in Power Co. v. Lefevre (1900) 55 S. W. 396 (Tex. Civ. App.) There an adult son was killed. The court refused to decide whether the mother might recover if contributory negligence on the part of the father should be shown but said that such recovery by the mother might well be separate. The statute gave a separate right of recovery to each parent. The jury in that case gave judgment in the sum of $\$ 4000, \$ 1000$ being for the father and the remainder for the mother. See also Bohan v. Bohan (1900) 56 S. W. 959 (Tex. Civ. App.).

64 Vinette v. N. P. Ry. Co. (1907) 47 Wash. 320, 91 Pac. 975, 18 L. R. A. (N. S.) 328; Keena v. United Railroads, supra, n. 38. According to the Supreme Court of California, this is because the wife represents the husband as head of the community, her negligence being imputed to him. See note "Imputed Negligence" in 31 Yale Law Journal, 639. App.).

${ }^{65}$ St. L. \& S. W. Ry. Co. v. Campbell (1903) 75 S. W. 564 (Tex. Civ. 
denied. ${ }^{66}$ The injuries to the mother and consequently the damages may have been increased by the delicacy of her condition, but there is no recovery allowed for grief occasioned by the loss of the child.

\section{d. Actions on Liquor-Dealers' Bonds}

Causes of action arising from obligations imposed by law upon liquor dealers for selling drink to the husband are likewise separate. Thus, in Hahn v. Goings, ${ }^{67}$ the husband and wife had jointly recovered for the wrongful sale of liquor to the husband on one bond and the wife had recovered alone upon another. The attorney for plaintiffs had collected the two judgments and interpleaded the spouses, the wife claiming the sums recovered as separate and the husband claiming them as community. It was held that they were separate because the statute gave to the wife the right to bring the action. It may well be that this kind of action was beyond the purview of the community property statutes but it is scarcely sufficient to say that such damages are separate because the wife may sue alone therefor. It is easily possible for the legislature to make the wife the community agent for this purpose, as has been done in California with reference to recovery for injuries to the wife. Moreover, such recoveries are community at least within the letter of the statutes.

If, however, the action is based on a sale of liquor to a minor instead of to the husband, such damages are community and the wife cannot sue alone. If the husband refuses to bring the action as the real party in interest he cannot be joined pro forma and the action be brought in the wife's name. ${ }^{.8}$

\section{e. Torts of Spouses Inter Sese}

It may be observed that in the community property states there has as yet been no recovery allowed to one spouse for the tort of the other either during the marriage relation or after it has terminated. Thus in Peters v. Peters, ${ }^{89}$ the wife shot the husband in the leg with a shot-gun, severely wounding him, wholly without

${ }^{66}$ Hawkins v. Front Street Cable Co. (1892) 3 Wash. 592, 28 Pac. 1121, 28 Am. St. Rep. 72; W. U. Tel. Co. v. Cooper (1888) 71 Tex. 507, 9 S. W. 598, 10 Am. St. Rep. 772; Schneider v. Biberger, supra, n. 32. See "Death" 17 C. J. $\$ \S 47$ and 50.

67 (1900) 22 Tex. Civ. App. 576, 56 S. W. 217. See Art. 7452 and notes, especially note 23, Vernon's Sayles' Tex. Civ. Stats.

68 Wartelsky v. McGee (1895) 10 Tex. Civ. App. 220, 30 S. W. 69. See other cases cited in Art 7452, notes 17, 21 and 23, Vernon's Sayles' Tex. Civ. Stats.

${ }_{69}$ (1909) 156 Cal. 32, 103 Pac. 219. 
justification. Although actions between spouses may now be maintained concerning property because the statutes permit husband and wife to contract inter sese with reference thereto, yet the common-law rule prevails with reference to torts. In Nickerson $v$. Nickerson, ${ }^{70}$ the spouses were living apart from each other. The husband and one $M$. caused the arrest of the wife and children for the purpose, as alleged, of depriving the wife of the children. After divorce the former wife sued both parties. It was held that the suit was maintainable by her alone against $M$. but not against the former husband, and that the sum recoverable would not be community property although the cause of action arose during the continuance of the nuarriage relation, because the husband, being a joint tort-feasor, could not have sued. This is going a long way toward overturning the common-law rule. Such acquisitions are outside the contemplation of the community property statutes and there would be no remedy against $M$. at all if the divorced wife could not sue him.

\section{f. Necessary and Proper Parties Plaintiff}

Probably the most discussed problem connected with the recovery of damages for personal injuries to the wife has to do with who shall be parties plaintiff. Growing out of this also is the problem of joinder of causes; $i$. e., may a cause for injuries to the wife be joined with one for consequential damages arising from loss of services, expenses, etc., which has been suffered by the community? Since in most states, and until recently in all, damages for injuries suffered belong to the community, it would seem that the husband, as the managing agent of the marital community, would in general be the only necessary party plaintiff. The following views are, however, current:

(1) Both spouses are necessary parties;

(2) The husband is the only necessary and proper party plaintiff.

(3) The husband is a necessary party and the wife is a proper party ;

(4) The wife is the only necessary party if she is deserted. If the wife sues alone she must show that she is living apart from the husband without her fault, or that the husband's refusal to join amounts to a waste of community property.

70 Supra, n. 36. See Speer, $\$ \S 268,323,433$. See also "Recognition of New Interests in the Law of Torts" by E. F. Albertsworth. 10 California Law Review, 461 at page 471 ; and 36 Harvard Law Review, 346. 
Until recently the first view that both must join was the California view: ${ }^{71}$ Under a recent statute the wife may now sue alone there. $^{72}$ This is the only case in which the wife may normally sue for the recovery of community property and it is recognized by the California court as an anomaly. ${ }^{73}$ One may conjecture that the reason is that in the early cases the court failed to observe that the common-law action for injuries to the wife must be brought in the name of both husband and wife, just as any other cause of action accruing to her, though the damages when recovered belonged to the husband, whereas damages recoverable in community property states for injuries to the wife belong to the community, so that the requirement that she must join is inconsistent with the community property law which makes the husband the managing agent. $^{74}$

One of the serious inconveniences resulting from the California view that the wife must join is that consequential damages may not be recovered in the same action because the wife cannot in any other case sue for recovery on a community cause of action. ${ }^{75}$ Fortunately such a view is now confined to California so far as has been observed by the writer. Idaho at one time held to exactly the same rule as California but that view has been rejected recently, though by a divided court ${ }^{78}$

The second view, that the husband is the only necessary or proper party plaintiff, is adhered to in $\operatorname{Texas}^{77}$ and Louisiana ${ }^{78}$ (though not very rigidly), and exceptions to misjoinders are cons-

71 The cases have consistently followed the early case, Sheldon v. Steamship Uncle Sam (1861) 18 Cal. 527, 79 Am. Dec. 193.

72 Supra, n. 29.

73 Moody v. So. Pac. Ry. Co. (1914) 167 Cal. 786, 141 Pac. 388; Gomez v. Scanlan, supra, n. 36.

74 Labonte v. Davidson (1918) 31 Idaho 644, 175 Pac. 588.

75 Easton v. Contracting Co. (1916) 173 Cal. 199, 159 Pac. 597; Tell v. Gibson (1884) 66 Cal. 247, 5 Pac. 223, and many other cases.

${ }_{76}$ Giffen v. City of Lewiston (1898) 6 Idaho 231, 55 Pac. 545 ; Lindsay v. O. S. L. Ry. Co. (1907) 13 Idaho 477,90 Pac. 984,12 L. R. A. (N. S.) 184. See note in 2 A. L. R. 592.

7T Feille v. S. A. Tr. Co. (1908) 107 S. W. 367 (Tex: Civ. App.) ; G. H. \& S. A. Ry. Co. v. Baumgarten (1903) 31 Tex. Civ. App. 253, 72 S. W. 78; W. U. Tel. Co. v. Cooper (1888) 71 Tex. 507, 9 S. W. 598, 10 Am. St. Rep. 772, 1 L. R A. 728; T. C. Ry. Co. v. Burnett (1884) 61 Tex. 638. But though the wife is not a formal party she is in legal effect a party so that the judge is disqualified to sit if plaintiff's wife is a sister of the judge's wife. The Texas statutes, Arts. 4694-4704a, apparently authorize an action by both spouses for death of a child by wrongful act and provide that an apportionment shall be made. In one case, Brush etc. Co. v. Lefevre (1900) $55 \mathrm{~S}$. W. 396 (Tex. Civ. App.), there is a dictum to the effect that such an apportioned judgment to the wife was separate. The case was reversed on another point in 93 Tex. 604, 57 S. W. 640 . See Speer, \& 441.

78 White v. Vicksburg R. Co. (1890) 42 La. Ann. 990, 8 So. 475. 
monly sustained. There seems to be some tendency to hold that the wife should join, where the action is for death of children by wrongful act, though she is not a necessary party. ${ }^{79}$ Of course under this view the causes for direct and for consequential damages may be joined.

The third view, that the wife is a proper but not necessary party plaintiff, is followed in Washington, ${ }^{80}$ and is based on statutory provisions which expressly permit her to be joined, but the husband is the only necessary party plaintiff. The two causes may be joined here also. Probably this is also the present rule in Idaho. In Labonte v. Davidson, ${ }^{81}$ an action was brought by both spouses for damages for injuries to the wife caused by an assault and battery, and for consequential damages. Defendant demurred for misjoinder of parties and of causes. Morgan, J., referring to the former holding that husband and wife must join in such cases, curtly said: "The latter holding is not the law."

The wife may sue alone if deserted or if living apart from the husband without fault on her part.82 Perhaps this rule would be followed in all the States and in some it is statutory. ${ }^{83}$ In Texas, the surviving wife may sue alone for injuries to herself, ${ }^{84}$ and the amount recovered is separate because it was not reduced to judgment during the continuance of the marital relation.

79 Posener v. Long (1913) 156 S. W. 591 (Tex. Civ. App.); San A. St. Ry. Co. v. Melcher (1894) 87 Tex. 628, 30 S. W. 899 ; S. W. Tel. \& T. Co. v. Dale (1894) 27 S. W. 1059 (Tex. Civ. App.); C. R I. \& G. Ry. Co. v. Oliver (1913) 159 S. W. 853 (Tex. Civ. App.); San A. St. Ry. Co. v. Helm (1885) 64 Tex. 147 ; Speer, \$ 443.

80 Hawkins v. Front St. Cable Co. (1892) 3 Wash. 592, 28 Pac. 1021, 28 Am. St. Rep. 72; Maynard v. Jefferson Co. (1909) 54 Wash. 351, 103 Pac. 418; Matthews v. City of Spokane (1905) 37 Wash. 223, 79 Pac. 784; Hynes v. Colman Dock Co. (1919) 108 Wash. 642, 185 Pac. 617. The same rule obtains in Porto Rico probably; see Vazques v. Valdes (1920) 28 P. R Rep. 431.

81 Supra, n. 74.

82 City of San Antonio v. Wildenstein (1908) 109 S. W. 231 (Tex. Civ. App.) ; Davis v. Davis, supra, n. 36; St. L. \& S. W. Ry. v. Griffith (1896) 35 S. W. 741 (Tex. Civ. App.) ; Leeds v. Reed (1896) 36 S. W. 347 (Tex. Civ. App.) ; Elzell v. Dodson (1883) 60 Tex. 331 ; M. K. \& T. Ry. Co. v. Hennesey (1899) 20 Tex. Civ. App. 315, $49 \mathrm{~S}$. W. 917. If the husband is insane, the action for injuries to him should be brought by his guardian. T. \& P. Ry. Co. v. Bailey (1892) 83 Tex. 19, 18 S. IV. 481 ; Speer, $\$ 441$.

$\$ 3$ Baldwin v. Cable Ry. Co. (1888) 77 Cal. 390,19 Pac. 644. (There was no express declaration that the damages recovered were separate.) See Cal. Code. Civ. Proc., \& 370.

8ะ Texas \& P. Ry. Co. v. Watkins (1894) 26 S. W. 760 (Tex. Civ. App.). In Washington, O'Toole v. Faulkner (1904) 34 Wash. 371, 75 Pac. 975, it was said that where the husband dies before the action is brought, the community was interested at least in the special damages, but it was thought to be doubtful whether, the community being dissolved, there was such an entity as could be continued through the administration for the purpose of sharing the proceeds of unliquidated and unrecovered damages for the continuing disabilities 
4 wife living with her husband cannot sue alone for injuries to herself, ${ }^{85}$ unless the statute expressly authorizes it. She does not own the cause of action. She cannot make a binding contract with attorneys to sue for her. ${ }^{86}$ If the husband does not join there must be a sufficient reason shown and, so far, none has ever been shown apart from statute, if the spouses were cohabiting, It is intimated that if the husband's refusal to join amounts to a waste of the community substance she might sue without him. In Rice v. The Mexican National Railway $\mathrm{Co}_{.}{ }^{87}$ the wife brought an action alleging that the husband refused to sue. This being an insufficient showing to permit her to bring the action, an amended complaint was filed in which the husband was joined. At this time the statute of limitations had run.

Where an action by the husband is pending and he dies, such action does not abate but may be continued in the name of his personal representatives. ${ }^{88}$ Likewise where the husband dies pending an action brought in the name of both spouses, it may be prosecuted by the wife personally by joining herself also as executrix of his will.89

As the wife cannot sue alone, neither can she execute a release so as to prevent the husband from bringing an action, because she is not the owner of the cause of action..$^{90}$ Likewise, a divorced wife cannot sue alone on a cause of action for injuries to herself that accrued during the marriage, there having been no account taken of it at the time of divorce.91

Under the California rule, ${ }^{92}$ judgment should run to both, though the damages are community property. The same result is

of a surviving member. The surviving wife sans appointment as administrator may sue for injuries to the husband in Texas, M. K. \& T. Ry. Co. v. Groseclose, supra, n. 39. Cf. also Walker v. Abercrombie (1884) 61 Tex. 69; no administration having been taken out on deceased husband's estate, the widow was permitted to sue and so to prevent the statute of limitations from running.

85 Hynes v. Colman Dock Co. (1919) 108 Wash. 643, 185 Pac. 617; Lamb

v. Harbaugh (is95) 105 Cal. 680, 39 Pac 56.

${ }_{86}$ Hammond v. Jackson (1916) 89 Wash. 510, 154 Pac. 1106.

87 (1894) 8 Tex. Civ. App. 130, 27 S. W. 921.

85 Fordyce y. Dixon (1888) 70 Tex. 694, 8 S. W. 504 . This case seems distinguishable from Texas. etc. v. Watkins, supra, n. 84 , on the ground that the action had been begun here but not in the Watkins case. No sufficient reason is shown why a vested community interest should be divested by the death of a spouse so as to become separate. Gomez v. Scanlan (1909) 2 Cal. App. 579, 84 Pac. 50, 102 Pac. 12, accord.

89 O'Toole v. Faulkner, supra, n. 84.

90 Justis v. Atchison: R. R. Co. (1910) 12 Cal. App. 639, 108 Pac. 328.

The wife also cannot elect the form of action to be brought.

91 Schneider y. Biberger, supra, n. 32.

92 Neale v. Depot Ry. Co. (1892) 94 Cal. 425, 29 Pac. 954. 
reached in other states where the wife is not a necessary but a proper party. It has been held also that no apportionment of the judgment is necessary. ${ }^{93}$ This may be because in all states but California the spouses have a beneficially equal interest in all the community assets. Of course the husband can make a gift to the wife of a cause of action for personal injuries to her so that she may sue alone.94

In Magnunson v. O'Dea, ${ }^{95}$ the divorced wife who had maintained her child ior several years was permitted to bring action for kidnapping the child without joining the father of the child as a party, because the father had apparently abandoned the child. If he were supporting the child, we are to infer that they would be joint owners of the cause of action. In this instance the wife had married again and the second husband treated the child as a member of his family. It was held that he was a necessary party plaintiff. Presumably, then, the damages recoverable would belong to this second community, just as the earnings of a husband's stepchildren who live in his houschold are community, when such children are received into his family.

\section{g. Putative Marriages}

A putative wife cannot recover for injuries suffered by her putative husband not resulting in his death, where he dies before the action was brought. A discussion of the rights of a putative wife comes more properly in a discussion of marriage as a prerequisite to the institution of the community. Several states have recognized putative marriages and there has been at times a tendency to treat a marriage entered into in good faith by one or both parties as resulting in the same rights as if the marriage were valid. In Fort Worth Railway Co. v. Robertson, ${ }^{96}$ it was held that the only acquisitions that such a wife could clain a share in were the fruits of their joint labors.

93 Posener v. Long (1913) 156 S. W. 591 (Tex. Civ. App.) ; San Antonio St. Ry. Co. v. Melcher (1894) 87 Tex. 628, 30 S. W. 899 . Cf., however, Houston City St. Ry. v. Sciacca (1891) 80 Tex. 350, 16 S. W. 31; M. K. \& T. Ry. Co. v. Evans (1897) 16 Tex. Civ. App. 68, 41 S. W. 80.

94 Perkins v. Sunset T. \& T. Co. (1909) 155 Cal. 712, 103 Pac. 190.

95 (1913) 75 Wash. 574, 135 Pac. 640.

96 (1913) 103 Tex. 504, 121 S. W. 202, 131 S. W. 400, Ann. Cas. 1913A. 231 , and note. See comment on this case, 10 Columbia Law Review, 79, approving the result reached in the Court of Civil Appeals in $131 \mathrm{~S}$. W. 202, which was subsequently reversed by the Supreme Court. A fortiori, a putative wife cannot recover damages for death of the putative husband by wrongful act. Vaughan v. Dalton-Lard Iumber Co. (1907) 119 La. 61, 43 So. 926. 


\section{Conclusion}

In summing up, one may observe that the proceeds of life insurance policies taken on the life of either spouse in favor of the other are invariably separate. Probably the surrender value would likewise be held separate where a liquidation has taken place, if no right in the insured to change the beneficiary were reserved in the policy. This is not, however, the necessary result where there is a surrender of a policy on the life of the wife. If such liquidated sum should be held the separate property of the husband, he would thus be enabled in effect to make himself directly a gift of community property. If we assume the rule, declared by Professor Vance to be supported by the weight of authority, where there is a right to change the beneficiary, it would seem that all sums acquired by surrender of the policy, issued on the life of either spouse, would be community, being of the nature of the funds used to procure the policy, if the funds used belonged to the community. The result would be analogous to that where trust funds are used. The proceeds of policies procured during marriage payable to insured's estate, and paid for with community funds, should always be regarded as the property of the community, and that view has the weight of authority. Conversely, insurance procured before marriage, or paid for after marriage with separate funds, should be separate unless payable to the other spouse as a beneficiary. Where the direction of the insurance has been finally determined before narriage but community funds are used thereafter, the community should be indemnified.

In order that damages for personal injuries may be the property of the community they must arise from injuries suffered during marriage and the action therefor must be for the recovery of damages for injuries strictly and not brought for death by wrongful act under such statutes as Lord Campbell's Act. Damages for the death of a child by wrongful act and damages arising from the abduction of children or stepchildren belong to the community, being acquired in a manner other than by gift, devise or descent, during the continuance of the marriage relation. The rule that requires an action for injuries to the wife to be brought either by both spouses, as once in California, or, as now, either by both or by the wife alone, seems to the writer wrong in principle. It works a hardship, necessitating as it does two actions in most cases. In that regard the Idaho rule seems sound.

Alvin E. Evans.

George Washington University,

Washington, D. C. 